\title{
Protecting Arctic Ocean Marine Biodiversity in the Area Beyond National Jurisdiction
}

\section{Plausible Legal Frameworks for Protecting High Arctic Waters}

\author{
Kamrul Hossain and Kathleen Morris
}

\section{Introduction}

An estimated $30 \%$ of the world's undiscovered gas and $13 \%$ of the world's undiscovered oil lies in the Arctic, most of it offshore. ${ }^{1}$ Once impossible shipping routes - such as the Northern Sea Route and even a possible transarctic routeappear increasingly feasible due to sea ice melt. ${ }^{2}$ Arctic shipping traffic as a whole is anticipated to increase in coming years due to ice melt allowing for longer shipping seasons (see footnote 2). Past sea ice melt indicates that the Arctic may be ice-free within decades, opening waters-and resources-previously sheltered by ice from mankind's exploits. ${ }^{3}$ Once protected by ice, the vast northern landscape compares in size to Africa and exists as one of Earth's final pristine ecosystems. ${ }^{4}$ Further, its wealth of resources includes more than oil, with living resources that include 5000 animal species; 2000 types of algae; and tens of thousands of ecologically critical microbes. ${ }^{5}$

\footnotetext{
${ }^{1}$ Eurasia Group for The Wilson Center (2013), p. 3.

${ }^{2}$ Emmerson and Lahn (2012), pp. 29-30.

${ }^{3}$ Wang and Overland (2012), pp. 4-5.

${ }^{4}$ Hossain (2014), pp. 18-20.

${ }^{5}$ Arctic Biodiversity Assessment Report (ABA) (2013), Chapter 14, p. 488.

K. Hossain $(\bowtie)$

Northern Institute for Environmental and Minority Law, Arctic Center, University of Lapland, Rovaniemi, Finland

e-mail: khossain@ulapland.fi

K. Morris

Department of International Relations, University of Southern California, Los Angeles, CA, USA

e-mail: krmorris@usc.edu
} 
Present economic opportunity in the Arctic is only possible through a fundamental challenge to Arctic biodiversity: rapid climate change brought on by global warming. ${ }^{6}$ The year 2015 proved to be the warmest year on record. ${ }^{7}$ Globalwarming-caused sea ice melt will not only pressure the Arctic marine ecosystem but also allow for anthropogenic activity and disturbances in previously unreachable parts of the Arctic Ocean. Opening waters promise to enable heightened resource extraction, tourism, shipping and navigation, and fishing activity. Arctic and non-Arctic states alike now express competitive economic stakes in the region in what has been termed the next "Great Game." 8 Thus, dual pressure of climate change and anthropogenic activity may threaten the living resources unique to the Arctic. Considering these economic and geopolitical shifts, it is worthwhile to consider whether current international law, such as the Law of the Sea, is sufficient to govern a changing region and protect its marine environment.

In anticipation of broader economic activity and environmental threat in the region-brought on by sea ice melt and the emergence of other states as stakeholders - the five Arctic coastal states reaffirmed a commitment to the Law of the Sea, including the United Nations Convention on the Law of the Seas (UNCLOS), in the Ilulissat Declaration of March 2008. ${ }^{9}$ Prior to the Declaration, discourse over Arctic governance began to consider the need for a new international treaty to govern the region. Media, academia, and Arctic strategies of non-Arctic states expressed growing concern that the Law of the Sea, given its rudimentary framework, was not sufficient to govern the Arctic ecosystem in changing environmental and commercial contexts. The following text will consider: is a new international legal instrument necessary for the protection of the Arctic marine environment? We suggest that existing legal instruments, such as the UNCLOS, suffice to govern the region and enable more comprehensive environmental preservation, particularly in the form of marine protected areas (MPAs).

Our analysis examines current state-led efforts to designating large portions of the Arctic as "marine protected areas" (MPAs), which would limit human activity in protected waters in an effort to preserve marine biodiversity conforming to the approach known as ecosystem-based management (EBM). The principle of EBM emphasizes environmental cross-linkages that require collaborative ecosystem management transcending national jurisdictions and boundaries. ${ }^{10}$ In contrast, current discourse around resource exploitation of the region describes a likelihood of geopolitical "scramble for the Arctic," drawing parallels to European imperial

\footnotetext{
${ }^{6}$ Arctic Climate Impact Assessment (ACIA) (2005), pp. 247, 1017.

${ }^{7}$ Hottest year on record according to surface temperature data from GISS Surface Temperature Analysis (GISTEMP) See GISTEMP Team (2016).

${ }^{8}$ Borgerson (2009).

${ }^{9}$ The Ilulissat Declaration provides the clear and firm statement that there is no need to develop a new arrangement for Arctic governance. See Arctic Ocean Conference, May 27-29, 2008, Ilulissat Declaration (May 28, 2008).

${ }^{10}$ UNEP/GPA (2006), p. 4.
} 
competition over African resources. ${ }^{11}$ In this scramble, state interests, including prospects for control over shipping lanes, oil resources, and fishing rights, depend on the lineation of exclusive economic zone boundaries based on seabed claims. Thus, while transboundary environmental protection is critical, the current Law of the Sea system emphasizes the importance of said boundaries, for delineating states' rights to respective coastal waters and resources. As such, the growing need for Arctic MPA creation in areas beyond national jurisdiction poses a challenge to the contemporary limitations of Law of the Sea.

Moreover, a considerable portion of the Arctic Ocean-2.8 million square kilometers-lies in an area beyond national jurisdiction (ABNJ), thus falling beyond the exclusive economic zone (EEZ) of any state actor. ${ }^{12}$ Currently, global ocean management is hindered by the lack of a clear mechanism for MPA designation in ABNJs. Recent leadership by the Arctic Council established the goal of creating a pan-Arctic network of MPAs through piece-by-piece coordination of nation-led efforts to create MPAs within sovereign borders. ${ }^{13}$ As such, the High Arctic cannot be designated as part of the network due to its status in ABNJ. Thus, in the following chapter drawing from our article "Legal Instruments for Marine Sanctuary in the High Arctic," we examine the limitations of MPA creation in the high seas under the contemporary Law of the Seas. ${ }^{14}$ Our analysis will consider the ongoing process at the UN level to draft an internationally binding legal instrument on the conservation and sustainable use of marine biological diversity in the areas beyond national jurisdiction under the UN Convention on the Law of the Sea. ${ }^{15} \mathrm{We}$, however, also consider various legal mechanisms that provide a mandate for MPA creation even in $A B N J$ that could allow for a plausible management regime to protect marine biodiversity.

No set universal legal mechanism is currently recognized to enable MPA creation in the High Arctic with acknowledgement of the UNCLOS. So we evaluate potential legal justification for the creation of an MPA in the High Arctic ABNJ, by way of precedent of mandates such as the UNCLOS and UN Convention on Biodiversity (UNCBD). We conclude that while the UNCLOS and UNCBD do offer a legal mandate for High Arctic MPA creation, a regional multilateral agreement offers the best solution for High Arctic MPA creation in the next decades.

\footnotetext{
${ }^{11}$ Grindheim (2009), p. 1.

${ }^{12}$ The Pew Charitable Trusts.

${ }^{13}$ PAME International Secretariat (April 2015), pp. 1-76.

${ }^{14}$ Morris and Hossain (2016).

${ }^{15}$ UN GA Res. 69/292 of 19 June 2015.
} 


\section{The Arctic Ocean: A Critical Intersection of Competing and Common Interests}

According to the preamble of the United Nations Convention on Biological Diversity (CBD), there is an "intrinsic value of biological diversity and of the ecological, genetic, social, economic, scientific, educational, cultural, recreational and aesthetic values of biological diversity and its components." ${ }^{, 6}$ Beyond this inherent value of Arctic biodiversity, human enjoyment and cultural valuation add another layer of importance to the Arctic environment. The economic value of marine biodiversity lies in its ecosystem services, such as ability to provide food, genetic resources, climate regulation through carbon sequestration, and a basis for local jobs. ${ }^{17}$ Specific to the Arctic, critical industries such as environmental tourism depend on ecosystem health and preservation of biodiversity. Biodiversity is also critical to emerging medical science: biotechnology innovation depends on the genetic variability of marine species, with diverse physiological and biochemical properties resulting from evolution in extreme cold Arctic waters. ${ }^{18}$ The benefits of Arctic biodiversity are felt globally, as they affect species adaptation to climate change, the global economy, future medical science, and overall species diversity on Earth.

Presently, as a result of the increase in the levels of $\mathrm{CO}_{2}$ in the atmosphere, which accelerates melting of Arctic sea ice, Arctic biodiversity finds itself under the assault of anthropogenic climate change and ocean acidification. The Arctic Marine Shipping Assessment Report of 2009 concludes that sea ice melt will allow for ship navigation and resource extraction in areas previously covered by ice. ${ }^{19}$ Tourism, shipping, oil and gas exploitation, fishing, and other industry-related maritime activity might therefore increase in the Arctic. ${ }^{20}$ Thus, dual pressures-climate change and increased human activities-will stress the Arctic marine environment with dire implications for its unique biodiversity.

As the Arctic Ocean opens up to oil and gas extraction, countries have an economic interest in claiming sovereignty over the continental shelves underneath the Arctic Ocean. By virtue of Article 76 of the UNCLOS, such claim could extend to unlimited area of the ocean floor beyond 200 nautical miles, where the surface and subsurface waters above are still high seas subject to global commons (see Article 76). ${ }^{21}$ As of August 2015, four out of five coastal states of the Arctic Ocean (the United States being the exception) had filed their submissions to extend the limits of their continental shelves into the Arctic Ocean. ${ }^{22}$ Russia was the first

\footnotetext{
${ }^{16}$ United Nations, "Convention on Biological Diversity" (1992), p. 1.

${ }^{17}$ Fauria and Kettunen (2015). TEEB Report for the Arctic, pp. 32, 34, 36.

${ }^{18}$ Kattunen (2015), p. 11.

${ }^{19}$ Arctic Council. Arctic Marine Shipping Assessment 2009 Report, p. 4.

${ }^{20}$ Young (2010), pp. 165-166.

${ }^{21}$ United Nations Convention on the Law of the Sea. Article 76.

${ }^{22}$ Submissions To The CLCS (2015).
} 
country to lodge its submission in 2001, claiming almost half of the Arctic Ocean seabed as its extended continental shelf. ${ }^{23}$ In response to the request from the Commission on the Limits of Continental Shelf (CLCS) for resubmission with further data, Russia renewed its claims recently in 2015, claiming an even greater portion of seabed (see footnote 23). Norway submitted its claim in 2006 and received a final recommendation from the Commission on the Limits of Continental Shelf in 2009, whereas both Canada (partially) and Denmark submitted their claims in 2013 and 2014, respectively. ${ }^{24}$ The United States is not yet a party to UNCLOS and is thus not yet able to lodge any formal submission to the CLCS. However, it is worth noting that most extractable resources fall within undisputed areas, within the Arctic littoral states' EEZs.

\subsection{The Ilulissat Declaration: Reaffirming the Law of the Sea and Arctic Council Amid New Challenges}

While competing claims may appear to signal competing interests in the region, regional actions have largely been evidenced as cooperative. At the March 2008 Arctic Ocean Conference in Ilulissat, Greenland, the five Arctic coastal states (Canada, Denmark, Russia, the United States of America, and Norway) convened and signed the resulting Ilulissat Declaration, which reaffirmed the commitment to the Law of the Seas and to an "orderly settlement of any possible overlapping claims." ${ }^{25}$ The Ilulissat Declaration concluded that the Law of the Sea contained necessary provisions for responsible ecosystem management on the part of the five Arctic coastal states. Thus, the five Arctic coastal states reaffirmed their commitment to the existing legal framework for governance of the Arctic Ocean, under Law of the Sea. The Declaration also calls for heightened cooperation with the International Maritime Organization (IMO) to strengthen regulations to prevent pollution and accidents resulting from heightened ship traffic from shipping, tourism, resource development, and research vessels (see footnote 25). Despite appearing as an assertion of coastal state predominance in the region, the document reaffirms the five Arctic states' commitment to the Arctic Council, established in 1996, and other related forums (see footnote 25 ).

\footnotetext{
${ }^{23}$ Proelss and Müller (2008), pp. 651, 665-677.

${ }^{24} \mathrm{UN}$ Commission on the Limits of the Continental Shelf (CLCS).

${ }^{25}$ Arctic Ocean Conference, Ilulissat Declaration (May 28, 2008).
} 


\subsection{Changing Tides: The Inclusion of Non-Arctic States as Arctic Council Observers}

The largest challenge to the existing legal framework will instead likely come from states with no existing littoral rights in the region. The volume of applications for observer status in the Arctic Council increased notably in recent years. ${ }^{26}$ Non-Arctic states increasingly perceive national interest in the region due to economic prospects made available by an opening Arctic. In particular, East Asian states such as Japan and China see potential commercial gains expanding fishing areas and faster shipping routes enabling trade. ${ }^{27}$ Though previously lacking political status in the region, Asian influence has grown in the Arctic region by the way of gaining observer status on the Arctic Council. In 2013, China, India, Japan, Singapore, and South Korea all were granted observer status on the Arctic Council, along with Italy. ${ }^{28}$ Though observers are void of decision-making power, the observer status allows for non-Arctic states to influence indirectly by way of being involved on participation in working groups, financial contributions, project proposals, and verbal and written statements. ${ }^{29}$ China's Arctic strategy, as articulated by Chinese officials, cautiously reframes Arctic governance as being an international issue warranting recognition of non-Arctic states' interests due to common resources and shipping routes. ${ }^{30}$ As noted by Jakobson (2010), the former Chinese Assistant Minister of Foreign Affairs Hu Zhengyue said:

\section{When determining the delimitation of outer continental shelves, the Arctic states need to not only properly handle relationships among themselves, but must also consider the relationship between the outer continental shelf and the international submarine area that is the common human heritage, to ensure a balance of coastal countries' interests and the common interests of the international community. ${ }^{31}$}

Increased non-Arctic state involvement in the region may therefore challenge existing legal frameworks governing the high sea water column and complicate regional agreements in the Arctic. As previously mentioned, this contrasts with the Arctic 5 coastal states' bypass of the Arctic Council in favor of releasing the 2008 Ilulissat Declaration to reaffirm their commitment to using UNCLOS to settle any legal challenges in the Arctic, and suggesting the primacy of coastal states in the area. Amid growing interest of both observer states and coastal states, Oran Young

\footnotetext{
${ }^{26}$ The 2013 Kiruna Declaration welcomed China, India, Italy, Japan, Republic of Korea and Singapore as new Observer States. See Arctic Council Secretariat. Kiruna Declaration (2013).

${ }^{27}$ Jakobson (2010), p. 13.

${ }^{28}$ Arctic Council Secretariat. Kiruna Declaration (2013).

${ }^{29}$ Note that observer states' financial contributions cannot exceed those of Arctic States, except as directed by Senior Arctic Officials. See Arctic Council. Arctic Council Observer Manual for Subsidiary Bodies (2014).

${ }^{30}$ Jakobson (2010), pp. 9-10, 13.

${ }^{31}$ Jakobson (2010), p. 10.
} 
(2010) suggests that the Arctic Council finds itself at a point of "state change" in which its existing governance structure is challenged. ${ }^{32}$

While international actors might acknowledge the High Arctic marine environment (in the international water column) as a common resource, notions of how the common resource should be used can be expected to differ greatly. States that stand to gain economically from fishing rights and navigational routes have the potential to conflict with state and non-state actors on their visions for the conservation of the Arctic Ocean. Further, a growing body of influential observer states have eventually outnumbered the Arctic states themselves. Admittedly, the observers' mandate does not hold a significant role in decision making in the Arctic Council. The Arctic Eight may, however, find their individual interests in the Arctic complicated by a growing number of actors exerting pressure by way of expertise, written opinions, and funding power. At the 2011 Nuuk Ministerial Meeting, one Russian diplomat voiced the concern that a growing majority of observers might demand more rights, perhaps to the extent of designating the Arctic as "universal humankind heritage" on the model of the Antarctic. ${ }^{33}$ Thus, while present discourse often depicts non-Arctic observers as potential resource exploiters and obstacles to preservation, the growing influence of non-Arctic states in the region (particularly as Arctic Council observers) has the normative power to reframe the Arctic as a global commons of sorts mandating sweeping, collaborative protections. Thus, any observer state pressure to designate the Arctic as "universal humankind heritage" in need of a new legal regime would fundamentally challenge the status quo adherence to Law of the Seas for Arctic Ocean governance.

\subsection{Heightened Industry-Caused Pressure on Marine Species}

Market prices and technological barriers will likely temper any "rush for the Arctic," particularly in the case of oil. ${ }^{34}$ Rather, short-term maritime activity is anticipated to consist primarily of destination shipping. ${ }^{35}$ However, though potential grand-scale economic activity may be overstated, a lengthening navigational season (enabled by sea ice melt) in summer and spring creates greater potential for conflict between vessels and marine life.

Current late spring and summer month shipping generally takes place after marine mammals migrate through narrow choke points, such as the Bering Strait. ${ }^{36}$ However, a lengthening shipping season risks more collisions between mammals and vessels during times of migration and reproduction in early spring months.

\footnotetext{
${ }^{32}$ Young (2010), p. 168.

${ }^{33}$ Graczyk and Koivurova (2012), p. 5.

${ }^{34}$ Anderson (2009), pp. 198, 207-215.

${ }^{35}$ Lawson (2010).

${ }^{36}$ Arctic Council AMSA Report (2009), pp. 135-136.
} 
White Sea harp seals already undergo considerable pup mortality caused by collisions with marine traffic, as vessels often breach the ice in seal whelping groupings. ${ }^{37}$ As shipping becomes possible earlier in the spring, there is increased risk of ship-caused disruptions along sections of water that are key to migration patterns and life cycles, such as feeding and nursery areas. Thus, heightened and highly adaptive conservation efforts will be particularly important in protecting marine mammal life cycles and migration patterns in coming years.

Migration patterns will also change, complicating the issue of protecting areas critical to marine life stages. Fish stocks are particularly sensitive to temperature and are predicted to continue to move toward the northern pole in search of cooler waters. ${ }^{38}$ Sea-ice-dependent species in particular, such as polar bears and aquatic mammals, also continue to move pole-ward in the search of remaining sea ice. As sea ice continues to melt and species migration patterns and distributions shift northward, biologically significant populations will increasingly be found in the High Arctic. As the High Arctic also becomes vulnerable due to sea ice melt, species in an area beyond national jurisdiction will lie vulnerable, without the possibility of state-created marine protected areas to guard populations from ship traffic.

Other risks associated with heightened ship traffic and resource development include the introduction of non-native species, pollution, vessel collisions with marine life, noise pollution, and other disruptions to the Arctic marine ecosystem. ${ }^{39}$ Not only are disruptions more likely as sea ice melts and northern routes are opened to ships, but these disruptions are increasingly likely to occur in waters that are beyond national jurisdiction and currently cannot be protected by a single state.

\section{Need for Arctic Marine Protected Areas}

In response to worldwide human-induced environmental damage, the UN CBD identifies designation of protected areas as an important strategy for biodiversity conservation. The International Union for the Conservation of Nature/World Commission on Protected Areas (IUCN/WCPA) defines a protected area as:

clearly defined geographical space recognized, dedicated, and managed, through legal or other effective means, to achieve the long-term conservation of nature with associated ecosystem services and cultural values. ${ }^{40}$

The CBD's Aichi Target 11 established the goal of designating at least $10 \%$ of marine and coastal areas as protected areas by $2020 .{ }^{41}$ Only a few years away from

\footnotetext{
${ }^{37}$ Vorontsova et al. (2008), pp. 586-592.

${ }^{38}$ Michel et al. (2009), pp. 487-518.

${ }^{39}$ Arctic Council AMSA Report (2009), p. 5.

${ }^{40}$ Dudley (2008), p. 8.

${ }^{41}$ Secretariat of the Convention on Biological Diversity (2010).
} 
this deadline, merely $1.55 \%$ of Arctic marine and coastal waters were protected, OSPAR marine protected areas. ${ }^{42}$ Arctic terrestrial habitats are well protected by comparison, with $17 \%$ considered protected by the year $2000 .{ }^{43}$

Though an enormous gap exists between terrestrial and marine protections, the Arctic Council did identify the creation of a pan-Arctic marine protected area (MPA) network as being a primary goal for the region in 2015. However, industrial activities in Arctic waters and coastal areas are increasing, while MPA creation still crawls behind. According to the Beaufort Sea Partnership (2009), MPA creation can take approximately 10 years. ${ }^{44}$ Meanwhile, according to Wang and Overland's projections using 2007/2008 sea ice extant data, the Arctic is predicted to be nearly sea ice-free by $2037 .{ }^{45}$ Under current legal infrastructure for MPA creation, glacial melt may outpace the creation of any comprehensive High Arctic marine reserve.

Terrestrial conservation is generally aided by clear jurisdiction, whereas the jurisdictional nature of the seas is much more complicated. Marine living resources move from one jurisdiction to another, including in the high seas. This contrasts with land-based protection, in which accepted borders generally allow for clear-cut, nation-led conservation efforts. Of course, the UNCLOS does allow for national claims to some waters as it designates areas within 200 nautical miles as being within respective countries' jurisdictions (in their exclusive economic zones or EEZs). Even so, a considerable portion of the Arctic Ocean-1.1 million square miles of ocean-falls beyond any country's exclusive economic zone. ${ }^{46}$ Whereas the marine areas within national jurisdiction (falling within EEZ) can be protected by national regulations, as well as by regional agreements among coastal states, the high sea — an area beyond national jurisdiction-instead remains open to all states for free maritime use, following the general limits set by the UN Law of the Sea Convention.

No single state or governing body has sovereignty over the Arctic high seas, an ABNJ. So the discrepancy between terrestrial and marine reserve creation is further perpetuated by a perceived lack of any accepted legal instrument for multilateral protection efforts in the high seas. The UNCLOS protects states' sovereign rights in respective territorial waters, as well as rights to authority over the EEZ. The Convention, however, offers only rudimentary provisions in regard to high sea usage without having any concrete and adequate protection regime for the marine species occurring in the Arctic.

In lieu of a presently accepted legal framework for marine protected area creation in the ABNJ, the Arctic region presently adheres to a nation-led approach under the leadership of the Arctic Council and its working groups. This strategy

\footnotetext{
${ }^{42}$ OSPAR Commission (2013), p. 29; OSPAR Commission (2009), pp. 7-8.

${ }^{43}$ CAFF (2002), p. 4.

${ }^{44}$ Beaufort Sea Partnership (2009).

${ }^{45}$ Wang and Overland (2012), pp. 4-5.

${ }^{46}$ The Pew Charitable Trusts: Arctic Ocean International.
} 
notably restricts marine protections to areas already under national jurisdiction, in the exclusive economic zones of Arctic coastal states. As such, the Arctic high sea is left vulnerable. Warming waters will lead more species - and more ships - north while putting pressure on the existing ecosystem. Thus, we consider: what are the constraints and limits of the current initiative to build a pan-Arctic network of MPAs within EEZs? And if such an initiative cannot legally protect the Arctic high seas, what other legal pathways exist?

Specifically considering the challenge of protecting marine life in the High Arctic ABNJ, we will turn to examine potential legal mechanisms for MPA creation in Arctic areas beyond national jurisdiction: creation of an Antarctic-modeled Arctic sanctuary (see Sect. 5), an UNCLOS implementing agreement, an additional protocol to the UNCBD, and an Arctic specific regional agreement (see Sects. 6.1, 6.2, and 6.3, respectively). Our evaluation of both the limits and merits of the potential legal pathways leads us to suggest that a regional legal regime for MPA creation in the High Arctic offers the most politically feasible and expedient pathway to protection. This sort of legal regime, though limited in its capacity so long as non-Arctic states are not parties, would still hold normative power and set a critical precedent for the international community to recognize the importance of protecting the High Arctic's wealth of biodiversity.

However, we first turn to examine the existing pathway for protection: the stateled network coordinated by the Arctic Council.

\section{The Arctic Council's State-Led Pathway for MPA Creation}

Presently, under the UNCLOS, actors are constrained in their ability to create marine protected areas, particularly in the ABNJs, because MPAs cannot be established unilaterally in these areas. ${ }^{47}$ Rather, human activity in areas that fall outside of national jurisdiction instead can only be governed by international arrangements, to some extent within the framework established by the IMO (see footnote 46).

Current action for MPA creation in the Arctic follows a nation-led approach, in which state actors designate MPAs within their particular EEZs. In 2015, the Arctic Council articulated a commitment to the coordinated creation of marine protected areas with its publication of the PAME Framework for a Pan-Arctic Network of Marine Protected Areas.

So what is the Arctic Council's vision for this pan-Arctic network? The 2015 PAME Framework envisions the following:

An ecologically representative and well-connected collection of individual marine protected areas and other effective area-based conservation measures in the Arctic that operate cooperatively, at various spatial scales, and with a range of protection levels, in

${ }^{47}$ United Nations Convention on the Law of the Sea. 
order to achieve the long-term conservation of the marine environment with associated ecosystem services and cultural values more effectively and comprehensively than individual sites could alone. ${ }^{48}$

The report plainly states that the network is not intended to be legally binding (see footnote 49). So while regional cooperation on the pan-Arctic MPA network will establish reciprocity for compliance among the Arctic states, it will be limited in enforcement capability for Arctic and non-Arctic states alike. PAME describes the Framework as offering guidance, which the Arctic states can each use to designate their own MPAs according to their respective timelines, goals, and authorities (see footnote 49). Individual state's goals and domestic processes will therefore affect the effectiveness of creating a pan-Arctic MPA network. The PAME Framework states that differing prioritization of MPA creation among the Arctic coastal states-not to mention their ruling parties and publics' opinionswill be a challenge.

Further, while the Framework acknowledges that "linkeages" exist between the pan-Arctic MPA network and the high seas, the Framework currently neglects to call for direct action in the ABNJ (see footnote 49). Particularly as warming temperatures and sea melt drive both marine species and human activity toward higher latitudes in the ABNJ, a clear legal instrument for MPA creation in the High Arctic ABNJ proves increasingly critical.

\section{Arctic Sanctuary: Demand for an Antarctic Model Treaty}

Following a media wave in 2008 depicting a "Wild West" type rush for the Arctic, nongovernmental organizations and academics alike began to articulate demand for a new treaty to govern the Arctic. ${ }^{49}$ Greenpeace, for instance, calls for designation of an "Arctic Sanctuary" composed of 2.8 million square kilometers (out of a total Arctic Ocean size of over 14 million square kilometers), with strict regulation of shipping and prohibition of commercial fishing and hydrocarbon extraction. ${ }^{50}$ Like others, Greenpeace suggested that this be done by way of a new Arctic Treaty, rather than through existing international law such as UNCLOS. Greenpeace further suggested that the Arctic Council's mandate to protect the region's environment might allow it to pursue such a treaty even beyond its member states' jurisdictions (see footnote 51). According to Greenpeace, the Arctic Council's past use of binding treaties in the case of the Agreement on Cooperation and Marine Oil Pollution Preparedness and Response and the Arctic Search and Rescue Agreement might then serve as precedent for another treaty beyond member state EEZs (so long as consistent with existing international law such as UNCLOS) (see

\footnotetext{
${ }^{48}$ PAME (2015), pp. 1-76.

${ }^{49}$ Holmes (2011).

${ }^{50}$ Hamilton (2014), pp. 4-15.
} 
footnote 51). This notion of an "Arctic Sanctuary" of course invokes the existing Antarctic Treaty of 1959. The Antarctic Treaty was concluded in order to designate the area as a commons for scientific use, prohibiting mineral resource extraction, and for the peaceful use of the continent. The treaty further served to limit and regulate tourism in the area. Moreover, influential international bodies have also explicitly suggested that the Antarctic Treaty System (ATS) might serve as a model. ${ }^{51}$ In October 2008, the European Parliament meeting on Arctic Governance held in Brussels articulated interest in such an international treaty:

the Commission should be prepared to pursue the opening of international negotiations designed to lead to the adoption of an international treaty for the protection of the Arctic, having as its inspiration the Antarctic Treaty, as supplemented by the Madrid Protocol signed in 1991, but respecting the fundamental difference represented by the populated nature of the Arctic and the consequent rights and needs of the peoples and nations of the Arctic region; believes, however, that as a minimum starting-point such a treaty could at least cover the unpopulated and unclaimed area at the center of the Arctic Ocean. ${ }^{52}$

The Southern Pole conjures a similar image to the Arctic due to extreme cold conditions and a resulting fragile but critical ecosystem. Both regions have experienced the threat of expanding tourism and commercial activity, causing academics and the public alike to cite the Antarctic Treaty as a clear precedent for similar action in the Arctic. However, as the European Parliament conceded, the two regions differ in geographic nature as the Antarctic is a continental landmass surrounded by ocean while the Arctic is instead a body of water surrounded by landmass. Moreover, human settlements, including indigenous peoples having special interests, already populate the Arctic. The geopolitical significance of the Arctic is also not to be overlooked. Existing competing jurisdictional claims by coastal states may very well undermine such a treaty on the unclaimed center of the Arctic Ocean by the fact that more areas are under the process of being claimed, awaiting approval by the UN Commission on the Limits of the Continental Shelf. According to Oran Young and Paul Arthur Berkman's piece in Science Magazine (2009), these differences "rule out a similar treaty in the Arctic."53

While an international treaty might still be achieved with concessions for the notable differences between the two poles, it is worthy to consider whether such a treaty can be a feasible solution or if such a treaty best serves the interests of preserving the Arctic marine environment. In fact, an ATS-modeled international treaty may not be feasible or desirable. While a binding treaty like the ATS might possess greater normative power and pressure for compliance, the very strength of being legally binding also serves to hamper action. ${ }^{54}$ Legally binding treaties notably take considerable lengths of time for negotiation and enactment; a minimum of four years is typical for negotiation alone (see footnote 55). The process of

\footnotetext{
${ }^{51}$ Young (2010), p. 168.

${ }^{52}$ European Parliament (2008), "Resolution of 9 October 2008 on Arctic Governance."

${ }^{53}$ Berkman and Young (2009), pp. 339-340.

${ }^{54}$ Young (2010), pp. 181-184.
} 
ratification and negotiations might undermine the very intent of such a treaty, watering down its environmental protections until acceptable to all signatories. Moreover, the legal process - presumably requiring ratification of adjustments to the treaty-might hinder any such treaty's responsiveness to changes in scientific knowledge or Arctic environmental conditions (see footnote 55).

Of course, whether or not such an international treaty is desirable or expedient might not be the question of importance. Instead, is such a treaty necessary to protect the Arctic marine environment? Under existing international law, such as the UN Convention on Biodiversity and the UNCLOS, there already exists a mandate for the protection of the Arctic seas. Thus, MPA creation may not require a sweeping ATS-style treaty. Instead, clarification and extension of existing international legal frameworks may enable MPA creation.

\section{Looking to the High Arctic: Legal Obligation for MPAs in ABNJs}

Establishment of an MPA within the Arctic ABNJ would find its legal basis in UNCLOS Part XII, which establishes an obligation to protect the marine environment under Article 192. States also have a duty to protect rare and fragile ecosystems and the habitat of threatened species under UNCLOS Article 194 for the prevention of pollution of the marine environment and the duty to cooperate under Article 107. ${ }^{55}$ According to Molenaar and Elferink (2009), MPAs can be established in ABNJ within the framework of UNCLOS on the basis of Article 194(5). ${ }^{56}$ Article 194 (5) articulates the obligation to "protect and preserve rare or fragile ecosystems as well as the habitat of depleted, threatened or endangered species and other forms of marine life." The other articles of UNCLOS also lend support to the creation of MPAs in ABNJ for the purpose of, for example, conservation and management of living resources in Article 61. ${ }^{57}$ Finally, Article 145 establishes obligation for "the protection and conservation of the natural resources of the Area and the prevention of damage to the flora and fauna of the marine environment" (see footnote 19). The Area is defined by the Convention as the seabed and ocean floor and subsoil thereof, beyond the limits of national jurisdiction. The marine environment in the water column above the "Area" therefore also would fall beyond boundaries of national jurisdiction. ${ }^{58}$ Though there apparently exists a legal basis for the creation of an MPA in an ABNJ, there presently exists no accepted comprehensive legal framework for execution of such an obligation.

\footnotetext{
${ }^{55}$ United Nations Convention on the Law of the Sea. Article 76.

${ }^{56}$ Molenaar and Oude Elferink (2009), pp. 5, 9.

${ }^{57}$ United Nations Convention on the Law of the Sea. Article 61.

${ }^{58}$ United Nations Convention on the Law of the Sea. Article 1.
} 
In lieu of an existing legal framework to fulfill the obligation to protect the High Arctic marine environment, we suggest three other potential approaches for MPA creation in an ABNJ: an UNCLOS implementing agreement or a protocol under UNCBD or a regional agreement to be concluded among the Arctic states. The aforementioned strategies are drawn from the recommendations from experts at the international seminar "Towards a legal framework for the creation and management of cross-sectoral marine protected areas in areas beyond national jurisdiction" in Boulogne-sur-Mer, France, in 2011. ${ }^{59}$ The Boulogne-sur-Mer international seminar was organized by IUCN and Institute for Sustainable Development and International Relations (IDDRI) in partnership with the Agency for Marine Protected Areas, University of the Littoral - Opal Coast, the European Office for Conservation and Development, and the Nausicaá (National Sea Centre - Boulogne-sur-Mer) in an effort to identify avenues for the creation of MPAs in ABNJs. Twenty international experts collaborated in applying precedents of international law to create viable scenarios for the creation and management of MPAs in high seas by 2030 - the decade in which an ice-free Arctic summer is predicted. Findings from the seminar were to inform the United Nations at the Rio+20 Conference and the IUCN World Congress in 2012. ${ }^{60}$

\subsection{United Nations Convention on the Law of the Sea (UNCLOS) Implementing Agreement}

The UNCLOS, while providing legal mandate for conservation measures in ABNJs such as MPAs, lacks an implementing agreement to provide a legal framework for MPA creation in an area beyond national jurisdiction. Part XII of the Convention provides that states' sovereign rights in the marine area coexist with the duty to protect and preserve the marine environment (Article 193). ${ }^{61}$ UNCLOS establishes the general obligations of all states to safeguard the marine environment in its entirety while offering a structure for dealing with all sources of pollution at sea. The Rio+20 UN Conference on Sustainable Development in 2012 expressed particular interest in reforming the institutional framework for ocean governance, with particular attention to an amendment to UNCLOS that would address gaps in the current framework for conservation in ABNJs. ${ }^{62}$ The Rio+20 proposal referenced "possible development of a multilateral agreement" under UNCLOS specifically (see footnote 63). The proposal also necessitated the designation of a lead UN agency to manage MPA designation. With growing demand for an UNCLOS implementing agreement from within the United Nations, it appears that internal

\footnotetext{
${ }^{59}$ Druel et al. (2011), pp. 1-28.

${ }^{60}$ IOC/UNESCO, IMO, FAO, UNDP (2011), pp. 39-40.

${ }^{61}$ United Nations Convention on the Law of the Sea.

${ }^{62}$ IOC/UNESCO, IMO, FAO, UNDP (2011), pp. 39-40.
} 
pressure and public opinion exist. As a result, at the UN level the General Assembly established a Preparatory Committee to produce a draft text for an internationally binding legal instrument on the conservation and sustainable use of marine biological diversity in the ABNJ under UNCLOS. ${ }^{63}$ However, negotiating a treaty as such is a far-reaching process since the Committee has just had its first meeting from March 28 to April 8, 2016, with a timeline to report to the General Assembly on the draft by the end of 2017, at which point the Assembly will take effort to convene an international conference to negotiate the agreement. Even if the agreement were eventually materialized, the general scope of the potential agreement would not be capable of dealing with Arctic-specific critical conditions unless an Arctic chapter in it is agreed upon. ${ }^{64}$ Consequently, despite the Preparatory Committee's endeavor to address area-based management tools (ABMTs), including MPAs, ${ }^{65}$ a universal nature of the scope of the agreement would probably fall short of addressing critical specificities prevailing in the Arctic. Nevertheless, the creation of an implementing agreement through UNCLOS offers clearly a legitimate avenue for the creation and management of MPAs in ABNJs, enforceable for all signatories. Compared to regionally authorized MPAs, an UNCLOS implementing instrument would make all UNCLOS state parties to the agreement, following ratification on behalf of each signatory. By explicitly forging an implementation agreement for governance of the high seas under UNCLOS, all the state parties to UNCLOS would also be mandated to recognize an MPA in the Arctic high seas. While perhaps less expedient than a regional agreement, such expansion and clarification of the UNCLOS would mandate greater participation. Notably, this arrangement would also provide a legitimate avenue for enforcement under the International Tribunal for the Law of the Sea. ${ }^{66}$ However, an UNCLOS implementing agreement would require a complicated process of renewed ratification-possibly with less clarity as concerns Arctic-specific conditions. Thus, like Antarctic-modeled treaty making, this legal pathway presents similar complexity in the effective realization of such an implementing agreement, even under the UNCLOS.

\footnotetext{
${ }^{63}$ UN GA Res. 69/292 of 19 June 2015.

${ }^{64}$ Hossain (2016).

${ }^{65}$ See Chair's overview of the first session of the Preparatory Committee, Preparatory Committee established by General Assembly resolution 69/292: Development of an international legally binding instrument under the United Nations Convention on the Law of the Sea on the conservation and sustainable use of marine biological diversity of areas beyond national jurisdiction.

${ }^{66}$ Druel et al. (2011), p. 16.
} 


\subsection{United Nations Convention on Biological Diversity (UNCBD) Additional Protocol}

Though present international legal discourse gives prominence to the UNCBD, a mandate for the protection of the global marine environment might allow for a legal framework by way of an additional protocol. Article 5 establishes the obligation of contracting parties to cooperate with other contracting parties either directly or through international organizations in the interest of conserving biodiversity in areas beyond national jurisdiction. ${ }^{67}$ In the UNCBD's preamble, the Convention instructs its parties to use the precautionary approach in environmental conservation. The Conference of the Parties (COP) Decision II/10 reiterates the direction to use the precautionary approach in regard to marine environments. ${ }^{68}$ Given that all the Arctic states, excluding the United States, are party to the UNCBD, they are all subject to the mandate to use precautionary approach in marine governance.

The UNCBD possesses particular validity as a means for a legal framework for MPA creation due to the CBD's precedent of offering scientific insight on the designation of Ecologically or Biologically Significant Areas (EBSAs), criteria also used to create MPAs. ${ }^{69}$ The UNCBD already possesses significant expertise in the area, evidenced by the existing Working Group on Protected Areas. The Working Group's mandate explicitly calls for an effort to identify methods for MPA creation in areas beyond national jurisdiction that are consistent with existing international law. $^{70}$

The UNCBD has already created two additional protocols that serve as supplementary agreements to the original convention: the Cartagena Protocol and the Nagoya Protocol. ${ }^{71}$ The Nagoya Protocol in particular was agreed upon in order to create a clear legal framework for the satisfaction of the CBD objective of fair and equitable sharing of benefits from the use of genetic resources (see footnote 71). With these two protocols serving as precedent, a similar protocol might be enacted to create a transparent and formalized legal framework for the creation of MPAs even in areas beyond national jurisdiction, as the mandate for such action is provided in the UNCBD. And yet again, this type of framework requires a similarly lengthy process as is required for an implementing agreement under UNCLOS, making its realization both time consuming and complicated.

\footnotetext{
${ }^{67}$ UNCBD (1992).

${ }^{68}$ Conference of the Parties to the Convention on Biological Diversity, Jakarta, Indonesia, Nov. 6-17, 1995. Conservation and Sustainable Use of Marine and Coastal Biological Diversity, Decision II/10, Part XI, UNEP/CBD/COP/DEC/II/10.

${ }^{69}$ The EBSA criteria has been used in the past to aid in conservation targets by the Sargasso Sea Alliance (SSA) and OSPAR. See Freestone et al. (2014).

${ }^{70}$ Ad Hoc Open-ended Working Group on Protected Areas (2004).

${ }^{71}$ The Cartagena Protocol on Biosafety (2003).
} 


\subsection{A Regional Arrangement}

Marine protected areas in ABNJs already have been established in other areas of the globe under the auspices of regional arrangements. Such regional arrangements have been used to establish MPAs in high seas of the Northern Ocean, the Northeast Atlantic, the Mediterranean, and the South Pacific, though no such arrangement has been used comprehensively in the Arctic. ${ }^{72}$ The Convention for the Protection of the Marine Environment of the North-East Atlantic ("OSPAR Convention") of 1992 established the OSPAR Commission in order to foresee the conservation and protection of the North-East Atlantic marine area. The OSPAR Convention's preamble cites UNCLOS Article 197 as providing a mandate for global and regional cooperation of the marine environment. ${ }^{73}$ It is suggested that cooperation between OSPAR Convention, the regulatory body and legal instrument tasked with preserving environment and resources of the North-East Atlantic, and sectoral regulatory organizations, such as Regional Fisheries Management Organizations (RFMOs), offers a comprehensive model for cooperation to create a similar regional agreement. ${ }^{74}$ Though limited in its Arctic claims, OSPAR's work in Arctic ABNJs shows that successful precedent exists for a coalition of regional actors to approach MPA creation in the high seas. ${ }^{75}$ Similar models for MPA creation in ABNJ under the auspices of regional arrangements include the nonbinding Hamilton Declaration on Collaboration for the Conservation of the Sargasso Sea and under the Convention for the Protection of the Marine Environment and the Coastal Region of the Mediterranean (the ammended Barcelona Convention). ${ }^{76}$

Though no regional sea management organization exists within the Arctic, the Arctic Council might serve as a venue for the creation of similar regional organization to facilitate MPA creation within an ABNJ. The 1996 Ottawa Declaration established the Arctic Council of the eight Arctic states-Sweden, the Russian Federation, the United States of America, Finland, Norway, Canada, Iceland, and Denmark - to ensure circumpolar cooperation with particular focus on environmental protection and sustainable development. ${ }^{77}$ Greenpeace suggests that the Arctic Council's mandate to protect the Arctic environment might give it grounds for greater action, extending even beyond its respective countries' borders. ${ }^{78}$ The

\footnotetext{
${ }^{72}$ Rochette et al. (2014), pp. 109-117.

${ }^{73}$ OSPAR Convention For The Protection Of The Marine Environment Of The North-East Atlantic (1992), 1-33.

${ }^{74}$ Druel et al. (2011), pp. $10-11$.

${ }^{75}$ OSPAR in particular has pioneered efforts for MPA creation in ABNJs, in the North-East Atlantic Ocean. See Molenaar and Oude Elferink (2009), pp. 5, 9.

${ }^{76}$ The EBSA criteria has been used in the past to aid in conservation targets by the Sargasso Sea Alliance (SSA) and OSPAR. See Freestone et al. (2014).

${ }^{77}$ Arctic Council, "Declaration on the Establishment of the Arctic Council" (Ottawa, Canada, 1996).

${ }^{78}$ Hamilton (2014), pp. 4-15.
} 
Arctic Council has taken initiative to negotiate even binding regional agreements in areas beyond national jurisdiction through past efforts such as the Agreement on Cooperation and Marine Oil Pollution Preparedness and Response and the Arctic Search and Rescue Agreement. ${ }^{79}$ The precedent of binding treaties in waters beyond members' EEZs could serve as grounds for a regional treaty creating MPAs even beyond EEZs, though only binding for the eight Arctic states and other parties that choose to accede to the treaty through future signature and ratification.

Such a regional legal arrangement may prove to be more politically expedient compared to a UNCBD additional protocol or an UNCLOS implementing agreement. Common needs in the Arctic have resulted in notable past regional cooperation and governance arrangements. The Arctic Council possesses a mandate to protect the Arctic environment by way of the Ottawa Declaration, reaffirmed by the Arctic coastal states in the 2008 Ilulissat Declaration. Greenpeace suggests that the Arctic Council's mandate to protect the Arctic environment might give it grounds for greater action, extending even beyond its respective countries' borders. Past Arctic Council initiatives resulted in a number of binding and nonbinding agreements relating to the marine environment, creating precedent for regional approaches to Arctic Ocean governance. A binding agreement, to be concluded within the auspices of the Arctic Council, among the Arctic Eight might be used to coordinate MPA creation in the Arctic ABNJ. Further, PAME's existing work to create a pan-Arctic MPA network among the Arctic EEZs provides a reasonable foundation for an extension of the network into the high seas.

A regional-agreement-based MPA does not legally bind a nonstate party, thus remaining compliant with international law and UNCLOS. Further, coordination with international bodies such as the IMO is considered necessary to ensure that creation of an MPA in the high seas does not violate existing international maritime law. ${ }^{80}$ Compliance with UNCLOS does limit the ability of such a regional agreement to enforce high sea MPA observance among nonmembers. However, such regional agreement can establish powerful normative guidance and also achieve nonparty compliance through mutual observer status, which would establish reciprocity for the mutual acknowledgement of participating parties' protected areas. For instance, the OSPAR Convention cannot enforce MPAs for international actors not party to the Convention (abiding by UNCLOS), but the Convention has mechanisms to engage nonparty states operating in OSPAR waters. The 17 contracting parties can invite nonparty states to accede to the Convention, often through arrangements of mutual observer status or memorandums of understanding (MoUs), thus making the MPA in ABNJ more enforceable while acknowledging freedom of the high seas. Thus, an Arctic-style regional agreement modeled after OSPAR could provide a robust marine environmental governance regime.

\footnotetext{
${ }^{79}$ Arctic Council: Agreements. (2015, September 16).

${ }^{80}$ OSPAR in particular has noted the need for cooperation with international bodies such as the IMO. See OSPAR Commission (2012), p. 19.
} 
Thus, lacking a new legal framework under the UNCLOS and UNCBD, a regional agreement is arguably the most suitable tool in its enforcement capacity and ability to set a norm for nonparties to comply.

\section{Conclusion: A Regional Arrangement in Wait of a Formal Legal Framework}

A regional agreement will only enforce recognition of a High Arctic MPA among ratifying signatory member states, with limited capacity for enforcement. By comparison, a legal framework through an implementing agreement under UNCLOS would allow for wider reach, extending to all ratifying state parties. Further, such an arrangement would allow for an enforcement mechanism by way of the International Tribunal for Law of the Sea. The potential for an additional protocol to the UNCBD also should not be ignored, given past precedent, international scope, and existing expertise in the creation of protected areas. Both instruments would lend international scope and recognition for a High Arctic MPA while addressing a critical gap in existing global marine governance. Though increasing public pressure exists for such a framework, the near horizon for an ice-free Arctic obliges immediate and effective action. The complicated lengthy process in reaching a large-scale consensus, either for UNCLOS implementing agreement or for UNCBD Protocol, is challenging. In lieu of such an international agreement, a regional agreement offers to begin MPA designation in the Arctic high seas under existing legal mandates, and among only the eight Arctic states. Drawing upon the expertise and collaboration of the pan-Arctic MPA network within members' EEZs, the Arctic states under the auspices of the Arctic Council possess proficiency to begin MPA designation in the Arctic ABNJ. Increased use of such regional agreements to protect the global commons might provide the impetus for broader protection under the UNCLOS or UNCBD.

\section{References}

ACIA (2005) Arctic climate impact assessment. ACIA Overview report. Cambridge University Press

Ad Hoc Open-ended Working Group on Protected Areas (2004) Convention on biological diversity. https://www.cbd.int/convention/wgpa.shtml. Accessed 5 Apr 2016

Anderson A (2009) After the Ice: Life, Death, and Geopolitics in the New Arctic: "Too Many Ships, Too Soon?". Smithsonian, New York

Arctic Council (2009) Arctic Marine Shipping Assessment 2009 Report. http://www.arctic.noaa. gov/detect/documents/AMSA_2009_Report_2nd_print.pdf

Arctic Council (2014) Arctic Council observer manual for subsidiary bodies. https://oaarchive. arctic-council.org/handle/11374/939 
Arctic Council (2015, September 16) Agreements. http://www.arctic-council.org/index.php/en/ our-work/agreements. Accessed 4 Apr 2016

Arctic Council (1996) Declaration on the establishment of the Arctic Council. Ottawa, Canada. https://oaarchive.arctic-council.org/bitstream/handle/11374/85/00_ottawa_dec1_1996_signed $\% 284 \% 29$.pdf?sequence $=1 \&$ is Allowed $=y$

Arctic Council Secretariat (2013) Kiruna Declaration: on the occasion of the Eighth Ministerial Meeting of the Arctic Council. Kiruna, SW. https://oaarchive.arctic-council.org/handle/11374/ 93? show $=$ full

Arctic Ocean Conference, May 27-29, 2008, Ilulissat Declaration (May 28, 2008). http://www. oceanlaw.org/downloads/arctic/Ilulissat_Declaration.pdf

Beaufort Sea Partnership (2009) Beaufort Sea Partnership Integrated Ocean Management Plan (IOMP) for the Beaufort Sea: 2009 and Beyond. Beaufort Sea Planning Office, Inuvik, NT

Berkman PA, Young OR (2009) Governance and environmental change in the arctic ocean. Science 324:339-340. doi:10.1126/science. 1173200

Borgerson SG (2009, March 25) The Great Game Moves North. Retrieved via Foreign Affairs website. https://www.foreignaffairs.com/articles/global-commons/2009-03-25/great-gamemoves-north. Accessed 1 Apr 2016

CAFF (Conservation of Arctic Flora and Fauna) (2002) Protected areas of the arctic: conserving a full range of values. Ottawa, Canada

Chair's overview of the first session of the Preparatory Committee, Preparatory Committee established by General Assembly resolution 69/292: Development of an international legally binding instrument under the United Nations Convention on the Law of the Sea on the conservation and sustainable use of marine biological diversity of areas beyond national jurisdiction, http://www.un.org/depts/los/biodiversity/prepcom_files/PrepCom_1_Chair's_Overview.pdf

Conference of the Parties to the Convention on Biological Diversity, Jakarta, Indonesia, Nov. 6-17, 1995. Conservation and Sustainable Use of Marine and Coastal Biological Diversity, Decision II/10, Part XI, UNEP/CBD/COP/DEC/II/10. http://www.cbd.int/decision/cop/? $\mathrm{id}=7083$

Druel E, Billée R, Treyer S (2011) A legal scenario analysis for marine protected areas in areas beyond national jurisdiction. Report from the Boulogne-Sur-Mer Seminar, 19-21 September 2011

Dudley N (2008) Guidelines for applying protected area management categories. IUCN, Gland, Switzerland. https://portals.iucn.org/library/efiles/documents/PAPS-016.pdf

Emmerson C, Lahn G (2012) Arctic opening: opportunity and risk in the high North (Rep.). Available via Lloyd's of London website. https://www.lloyds.com/ /media/files/news and insight/360 risk insight/arctic_risk_report_webview.pdf. Accessed 12 Mar 2016

Eurasia Group for The Wilson Center (2013) Challenges for arctic oil and gas development. https://www.wilsoncenter.org/sites/default/files/Artic Report_F2.pdf. Accessed 15 Feb 2016

European Parliament (2008) Resolution of 9 October 2008 on Arctic Governance. http://www. europarl.europa.eu/sides/getDoc.do?type $=$ TA\&language $=$ EN\&reference $=$ P6-TA-2008-474. Accessed 12 Feb 2016

Fauria M, Kettunen M (2015) The Economics of Ecosystems and Biodiversity (TEEB) for the Arctic: a scoping study. CAFF International Secretariat, Akureyri, Iceland

Freestone D et al (2014) Can existing institutions protect biodiversity in areas beyond national jurisdiction? Experiences from two on-going processes. Mar Policy 49. doi:10.1016/j.marpol. 2013.12.007

GISTEMP Team (2016) GISS Surface Temperature Analysis (GISTEMP). NASA Goddard Institute for Space Studies. http://data.giss.nasa.gov/gistemp/. Accessed 9 Mar 2016

Graczyk P, Koivurova T (2012) A new era in the arctic council's external relations? Broader consequences of the Nuuk observer rules for arctic governance. Polar Record. doi:10.1017/ S0032247412000824 
Grindheim A (2009) The scramble for the Arctic? A discourse analysis of Norway and the EU's strategies towards the European Arctic. Fridtjof Nansen Institute, Lysaker, Norway. ISBN: 978-82-7613-566-4

Hamilton N (2014) Arctic Sanctuary. Greenpeace, June (2014). http://www.greenpeace.org/international/Global/international/publications/oceans/2014/Arctic\%20Sanctuary.pdf

Holmes JR (2011) The Arctic Sea-a New Wild West? The Diplomat. http://thediplomat.com/2011/ 04/the-arctic-sea-a-new-wild-west/. Accessed 04 Feb 2016

Hossain K (2014) An arctic challenge: areas beyond national jurisdiction. The Circle

Hossain K (2016) Arctic marine biodiversity in areas beyond national jurisdiction: framing a legally binding MPA regime? ASIL Insights 20(14). https://www.asil.org/insights/volume/20/ issue/14/arctic-marine-biodiversity-areas-beyond-national-jurisdiction-framing

IOC/UNESCO, IMO, FAO, UNDP (2011) A blueprint for ocean and coastal sustainability. Paris, France. http://www.uncsd2012.org/content/documents/interagency_blue_paper_ocean_rioPlus20. pdf

Jakobson L (2010) China prepares for an ice-free arctic. SIPRI Insights on Peace and Security, no. 2010/2. http://books.sipri.org/files/insight/SIPRIInsight1002.pdf

Kattunen M (2015) Business and ecosystem services: taking responsibility, identifying dependencies, seizing opportunities. The Circle 02.15

Lawson BW (2010) Think Again: The Arctic. Foreign Policy. http://foreignpolicy.com/2010/08/ 06/think-again-the-arctic/. Accessed 04 Jan 2016

Meeting of the OSPAR Commission (2009) OSPAR's Regulatory Regime for establishing Marine Protected Areas (MPAs) in Areas Beyond National Jurisdiction (ABNJ) of the OSPAR Maritime Area

Meltofte H (ed) (2013) Arctic Biodiversity Assessment (ABA). Status and trends in Arctic biodiversity. Ch. 14. Conservation of Arctic Flora and Fauna, Akureyri, Iceland

Michel C et al (2009) Arctic Biodiversity Assessment: Marine Ecosystems. Chapter 14, pp 487-518. http://www.caff.is/assessment-series/10-arctic-biodiversity assessment/219-arcticbiodiversity-assessment-2013-chapter-14-marine-ecosystems

Molenaar EJ, Oude Elferink A (2009) Marine protected areas in areas beyond national jurisdiction-the pioneering efforts under the OSPAR convention. Utrecht Law Rev

Morris K, Hossain K (2016) Legal instruments for marine sanctuary in the high arctic. Laws 5 (2):20. doi:10.3390/laws5020020

OSPAR Commission (2013) 2012 Status Report on the OSPAR Network of Marine Protected Areas - Biodiversity Series. http://www.ospar.org/ospar-data/p00618_20

OSPAR, Convention for the Protection of the Marine Environment of the North-East Atlantic, 1992. http://www.ospar.org/convention/text

PAME International Secretariat (April 2015) Framework for a Pan-Arctic Network of Marine Protected Areas: 1-76. Akureyri, Iceland. http://www.pame.is/images/03_Projects/MPA/ MPA_Report.pdf. Accessed 10 Dec 2015

Proelss A, Müller T (2008) The legal regime of the Arctic Ocean. Heidelberg J Int Law 68, 651, 665-677

Rochette J et al (2014) The regional approach to the conservation and sustainable use of marine biodiversity in areas beyond national jurisdiction. Mar Policy 49:109-117. doi:10.1016/j. marpol.2014.02.005

Secretariat of the Convention on Biological Diversity (2010) Strategic Plan for Biodiversity 2011-2020 and the Aichi Targets. Montreal, Canada. http://www.cbd.int/doc/strategic-plan/ 2011-2020/Aichi-Targets-EN.pdf. Accessed 16 Feb 2016

The Cartagena Protocol on Biosafety. Convention on Biological Diversity: http://bch.cbd.int/ protocol/ (2003). Accessed 05 Apr 2016

The Pew Charitable Trusts. Why an International Fisheries Agreement Is Needed in the Central Arctic Ocean FAQ. http://www.pewtrusts.org/en/projects/arctic-ocean-international/solutions/ faqs. Accessed 15 Feb 2016 
UNCBD (1992) Convention on Biological Diversity. https://www.cbd.int/doc/legal/cbd-en.pdf. Accessed 05 Apr 2016

UN Commission on the Limits of the Continental Shelf (CLCS). http://www.un.org/Depts/los/ clcs_new/commission_submissions.htm

UNEP/GPA (2006) Ecosystem-based management: markers for assessing progress. UNEP/GPA, The Hague. ISBN: 92-807-2707-9

UN GA Res. 69/292 of 19 June 2015. http://www.un.org/en/ga/search/view_doc.asp?symbol=A/ RES/69/292

United Nations Convention on Biological Diversity (1992). https://www.cbd.int/doc/legal/cbd-en. pdf

United Nations Convention on the Law of the Sea. http://www.un.org/depts/los/ convention_agreements/texts/unclos/unclos_e.pdf

UN News Center (3 August 2015) Submissions To The CLCS. http://www.un.org/Depts/los/ clcs_new/commission_submissions.htm. Accessed 25 Oct 2015

Vorontsova MN, Chernook VI, Glazov DM, Filipova AV (2008) Current threats to the survival of the harp seal (Phoca groenlandica) White Sea population. In: Proceedings of the Marine Mammals of the Holarctic. Odessa, October 2008. http://2mn.org/downloads/bookshelf/ mmh5_book/1-18.pdf

Wang M, Overland JE (2012) A sea ice free summer arctic within 30 years: an update from CMIP5 models. Geophys Res Lett 39(18). doi:10.1029/2012g1052868

Young OR (2010) Arctic governance - pathways to the future. Arct Rev Law Polit 1(2). https:// arcticreview.no/index.php/arctic/article/view/15. doi:10.17585/arctic.v1.15

Open Access This chapter is licensed under the terms of the Creative Commons AttributionNonCommercial 4.0 International License (http://creativecommons.org/licenses/by-nc/4.0/), which permits any noncommercial use, sharing, adaptation, distribution and reproduction in any medium or format, as long as you give appropriate credit to the original author(s) and the source, provide a link to the Creative Commons license and indicate if changes were made.

The images or other third party material in this chapter are included in the chapter's Creative Commons license, unless indicated otherwise in a credit line to the material. If material is not included in the chapter's Creative Commons license and your intended use is not permitted by statutory regulation or exceeds the permitted use, you will need to obtain permission directly from the copyright holder. 